\title{
Integrated Nutrient Management in Rice-Gingelly-Maize Cropping System Yield and System Economics through Integrated Farming System
}

\author{
K. Maruthupandi * and C. Jayanthi \\ Department of Agronomy, Tamil Nadu Agricultural University, \\ Coimbatore-625104, Tamil Nadu, India \\ *Corresponding author
}

\section{Keywords}

IFS, INM, RiceGingelly-Maize, Cropping system yield, System return, $\mathrm{B}: \mathrm{C}$ ratio

Article Info

Accepted: 24 June 2018 Available Online: 10 September 2018

\section{A B S T R A C T}

Field experiments were conducted at Wetland farm of Tamil Nadu Agricultural University, Coimbatore during 2014-2015 and 2015-2016 to study the effect of integrated nutrient management in rice-gingelly-maize cropping system. The field experiments were laid out in randomized block design with three replications and the same layout was maintained both the years. The experiment consisted of thirteen treatments comprising of three level of recommended dose of fertilizer (100, 75 and 50\% RDF combination with various organic sources (turkey, quail and goat manure as pond silt and vermicompost) and 100\% RDF along with FYM. In Rice-gingelly-cropping system during 2014-15 and 2015-2016, application of $100 \% \mathrm{RDF}+$ vermicompost at $5 \mathrm{t} / \mathrm{ha}\left(\mathrm{T}_{1}\right)$ recorded higher system yield of $15102 \mathrm{~kg} / \mathrm{ha}$ and $15551 \mathrm{~kg} / \mathrm{ha}$. This was followed by application of $100 \% \mathrm{RDF}+$ goat manure as pond silt at $5 \mathrm{t} / \mathrm{ha}\left(\mathrm{T}_{4}\right), 100 \% \mathrm{RDF}+\mathrm{FYM} 12.5 \mathrm{t} / \mathrm{ha}\left(\mathrm{T}_{13}\right)$ and $100 \% \mathrm{RDF}+$ turkey manure as pond silt at $5 \mathrm{t} / \mathrm{ha}\left(\mathrm{T}_{2}\right)$. The application of $50 \% \mathrm{RDF}+$ quail manure as pond silt at $5 \mathrm{t} / \mathrm{ha}\left(\mathrm{T}_{11}\right)$ recorded lesser system yield of $8876 \mathrm{~kg} / \mathrm{ha}$. In $2015-16$ followed by application of $100 \% \mathrm{RDF}+$ goat manure as pond silt at $5 \mathrm{t} / \mathrm{ha}\left(\mathrm{T}_{4}\right), 100 \% \mathrm{RDF}+$ turkey manure as pond silt at $5 \mathrm{t} / \mathrm{ha}\left(\mathrm{T}_{2}\right), 100 \% \mathrm{RDF}+\mathrm{FYM} 12.5 \mathrm{t} / \mathrm{ha}\left(\mathrm{T}_{13}\right), 75 \% \mathrm{RDF}+$ vermicompost at $5 \mathrm{t} / \mathrm{ha}\left(\mathrm{T}_{5}\right)$ and $100 \% \mathrm{RDF}+$ quail manure as pond silt at $5 \mathrm{t} / \mathrm{ha}\left(\mathrm{T}_{3}\right)$. The application of $50 \% \mathrm{RDF}+$ quail manure as pond silt at $5 \mathrm{t} / \mathrm{ha}\left(\mathrm{T}_{11}\right)$ recorded lesser system yield of $9310 \mathrm{~kg} / \mathrm{ha}$. It was comparable with application $100 \% \mathrm{RDF}+$ goat manure at 5 $\mathrm{t} / \mathrm{ha}$ recorded higher gross return and net return and $75 \% \mathrm{RDF}+$ vermicompost at $5 \mathrm{t} / \mathrm{ha}$ recorded higher B:C ratio of 2.69 and 2.78 during 2014-2015 and 2015-2016. Compare to conventional practices increased percentage of gross return (10.74 and 11.11) and net return (17.86 and 18.23) respectively during 2014-2015 and 2015-2016.

\section{Introduction}

Currently, the world population is increasing at alarming rate but there is no scope to increase the net cultivable land for crop production. Exploiting the production potential of high yielding rice based cropping system through agronomic management is one of the alternatives to feed the ever rising population. For this, fertilizers have 
contributed substantially to the spectacular increase in rice yield. This concept of nutrient management assumed greater significance in recent years because of two reasons. First, the need for continued increase in agricultural production and productivity requires growing application of nutrients and the present level of fertilizer production in India is not enough to meet the entire plant nutrient requirement.

A typical rice based system in South Asia follows traditional cultivation techniques that involve wet ploughing (puddling), followed by transplanting rice seedlings grown in a seedbed in the summer (Hobbs et al., 2008). Wheat or other crops in a rotation are grown in the winter using traditional desi plough or moldboard plough tillage. Improved management practices such as reduced or no tillage management, crop residue addition, crop rotation, and balanced nutrient application increases soil organic carbon (SOC) and improves agricultural sustainability (Six et al., 2002; West and Post 2002; Vanden Bygaart et al., 2003). Rice based cropping systems in South and Southeast Asia include irrigated continuous rice cropping, rice-wheat rotation and rainfed rice based mixed farming in upland areas which feed more than 1.5 billion people (Cassman, 1999). In South Asia, continuous rice cropping and rice-wheat rotation occupy approximately $26 \%$ of the cultivated land with additional $30 \%$ area under the rainfed mixed farming that includes upland rice production (FAO, 2001). Upland rice is produced in areas with low precipitation and limited opportunities for irrigation. There is a growing interest towards the use of conservation management systems, such as reduced tillage, no-tillage, crop residue addition, and improved nutrient management practices in rice and other crops in rotation for sustainably increasing food production in South Asia (Carter, 2002; Erenstein and Laxmi, 2008; Johnston et al., 2009), productivity by 3 per cent/annum (Thiyagarajan and Selvaraju, 2001).
Rice cultivation requires large quantity of water and for producing one $\mathrm{kg}$ rice, about 3000-5000 litres of water depending on the different cultivation methods such as transplanted rice, direct sown rice (wet seeded), alternate wetting and drying method (AWD), aerobic rice and rice based cropping system.

Owing to increasing water scarcity, a shifting trend towards less water demanding crops against rice is noticed in most part of the India and this warrants alternate methods of rice cultivation that aims at higher water and crop productivity. There are evidences that cultivation of rice based cropping system can increase rice equivalent yields by two to three fold compared to current yield levels.

The impending demand-supply gap of about 10 million tonnes of plant nutrients is likely to widen further in view of steep hike in the prices of $\mathrm{P} \& \mathrm{~K}$ fertilizers and raw materials. Second, a large number of experiments on INM, particularly long term experiments conducted in India or elsewhere reveal that neither the fertilizers nor the organic sources in isolation can achieve sustained production under intensive cropping.

\section{Materials and Methods}

Field experiments were conducted at Tamil Nadu Agricultural University, Coimbatore during rabi-summer-kharif seasons (Sep-Oct, Feb-Mar, June-July, respectively) in 2014-15 and 2015-16 to study the effect of integrated nutrient management for rice-gingelly-maize cropping system. The details of the experimental materials used and the methods adopted during the course of investigations are presented in this chapter. Experiments were conducted in Field No. M-8 at wetland farm of the Department of Farm Management, Tamil Nadu Agricultural University, Coimbatore. The experimental site is geographically situated in the western agro-climatic zone of 
Tamil Nadu at $11^{\circ} \mathrm{N}$ latitude and $77^{\circ} \mathrm{E}$ longitude and at an altitude of 426.7 meters above mean sea level (MSL).

During 2014-15, the crop received $198.4 \mathrm{~mm}$ of rainfall. The maximum and minimum temperatures ranged from $27.6^{\circ} \mathrm{C}$ to $36.2^{\circ} \mathrm{C}$ and $18.1^{\circ} \mathrm{C}$ to $25.5^{\circ} \mathrm{C}$, respectively. The mean relative humidity ranged from 65.8 to 93.1 per cent and 23.7 to 66.4 per cent during forenoon and afternoon, respectively. The mean bright sunshine hours ranged from 1.5 to 12.4 hours/day.

During 2015-16, the crop received $163.7 \mathrm{~mm}$ of rainfall. The maximum and minimum temperatures ranged from $27.3^{\circ} \mathrm{C}$ to $37.9^{\circ} \mathrm{C}$ and $16.7^{\circ} \mathrm{C}$ to $26.0^{\circ} \mathrm{C}$, respectively. The mean relative humidity ranged from 76.9 to 89.4 per cent and 25.4 to 64.6 per cent in forenoon and afternoon, respectively. The mean bright sunshine hours ranged from 1.0 to 0.1 hours/day

Table.2 Details of treatments

$\mathrm{T}_{1}-100 \% \mathrm{RDF}+$ vermicompost

$\mathrm{T}_{2}-100 \% \mathrm{RDF}+$ turkey manure as pond silt

$\mathrm{T}_{3}-100 \% \mathrm{RDF}+$ quail manure as pond silt

$\mathrm{T}_{4}-100 \% \mathrm{RDF}+$ goat manure as pond silt

$\mathrm{T}_{5}-75 \% \mathrm{RDF}+$ vermicompost

$\mathrm{T}_{6}-75 \% \mathrm{RDF}+$ turkey manure as pond silt

$\mathrm{T}_{7}-75 \% \mathrm{RDF}+$ quail manure as pond silt

$\mathrm{T}_{8}-75 \% \mathrm{RDF}+$ goat manure as pond silt

$\mathrm{T}_{9}-50 \% \mathrm{RDF}+$ vermicompost

$\mathrm{T}_{10}-50 \% \mathrm{RDF}+$ turkey manure as pond silt
$\mathrm{T}_{11}-50 \% \mathrm{RDF}+$ quail manure as pond silt

$\mathrm{T}_{12}-50 \% \mathrm{RDF}+$ goat manure as pond silt

$\mathrm{T}_{13}-100 \% \mathrm{RDF}+\mathrm{FYM}$ at $12.5 \mathrm{t} / \mathrm{ha}$

Note: RDF - As per the recommendation to the individual crop.

OM (turkey, quail, goat manures as pond silt and vermicompost) were applied to first crop (rice) only in the cropping system at $5 \mathrm{t} / \mathrm{ha}$.

\section{Preliminary trial}

\section{Experimental methods}

\section{Preliminary experiment}

Quantification of fish pond silt fed with fresh manures

Pond I: Turky (20 Nos.)

Pond II: Quail (80 Nos.)

Pond III: Goat (5+1 Nos.)

The preliminary experiment was conducted 9 months in fish pond for pond silt and manure production.

The nutrient analysed pond silt and manure was utilized for main experiment (Table 3 ) but the pond silt and manure cost was taken by at the time of marketing price. Here not added for any special cost of cultivation for pond silt and manure production through integrated farming system. Fish pond fallow in 3 months.

\section{Main field experiment}

\section{Crop management}

Field preparation: After the harvest of gingelly crop, each plot was prepared with 
ridges and furrows without disturbing layout plan then puddling to rice.

Manures and fertilizer application: Recommended dose of fertilizer of NPK in the form of urea $(46 \% \mathrm{~N})$, single super phosphate $\left(\begin{array}{lll}16 \% & \mathrm{P}_{2} \mathrm{O}_{5}\end{array}\right)$ and muriate potash $\left(60 \% \mathrm{~K}_{2} \mathrm{O}\right)$ were applied. Nitrogen and was applied in quarter dose as basal, remaining in 45 DAS, respectively. The entire dose of phosphorus and Potassium was applied as basal depend on the crop.

Seeds and sowing: seeds were dibbled at the rate of one seed/hill adopting spacing within the row. A required seed rate of was adopted. Seeds were dibbled manually and transplanting.

Gap filling and thinning: Gap filling was done on seventh day after sowing and thinning on $15^{\text {th }}$ day after sowing for all crops.

Irrigation: First irrigation was given immediately after sowing. Life irrigation was given on third day after sowing. Subsequent irrigations were given on need basis at an interval of 7-10 days.

Weed management: Application of preemergence herbicide atrazine $0.25 \mathrm{~kg} / \mathrm{ha}$ was done on third day after sowing. Hand weeding was done on $30^{\text {th }}$ DAS and necessary place.

Plant protection: Adequate need based plant protection measures were taken up periodically during the crop growth period as per recommendation of crop production guide (2012).

Two border rows on all four sides of each treatment plot were harvested first and then the net plots harvested separately. The harvested cobs were dried, dehisced, husk, shelled and cleaned separately. After cleaning, the grains were sun dried to 14 per cent moisture content. Grain weight of each treatment was recorded and expressed in $\mathrm{kg} / \mathrm{ha}$. Stover yield was also recorded and expressed in $\mathrm{kg} / \mathrm{ha}$.

\section{Results and Discussion}

\section{System yield}

Rice grain equivalent yield (System yield) was significant influence on system yield was observed during both the years of study and are presented in the Table 1. Mean system yield of two years revealed that, application of $100 \% \mathrm{RDF}+$ vermicompost at $5 \mathrm{t} / \mathrm{ha}\left(\mathrm{T}_{1}\right)$ recorded higher system yield of $15327 \mathrm{~kg} / \mathrm{ha}$. This was followed with application of $100 \%$ $\mathrm{RDF}+$ goat manure as pond silt at $5 \mathrm{t} / \mathrm{ha}\left(\mathrm{T}_{4}\right)$, $100 \% \mathrm{RDF}+\mathrm{FYM} 12.5 \mathrm{t} / \mathrm{ha}\left(\mathrm{T}_{13}\right)$ and $100 \%$ $\mathrm{RDF}+$ turkey manure as pond silt at $5 \mathrm{t} / \mathrm{ha}$ $\left(\mathrm{T}_{2}\right)$. The application of $50 \% \mathrm{RDF}+$ quail manure as pond silt at $5 \mathrm{t} / \mathrm{ha}\left(\mathrm{T}_{11}\right)$ recorded lesser system yield of $9093 \mathrm{~kg} / \mathrm{ha}$.

\section{System economics}

System economics and the viability of crop cultivation are mainly the outcome of the yield of crop (Table 2). Mean of two years data on recorded that system cost of cultivation higher system cost of cultivation and net returns of ₹ 83610 and $₹ 146287 /$ ha were observed with application of $100 \% \mathrm{RDF}+$ vermicompost at $5 \mathrm{t} / \mathrm{ha}\left(\mathrm{T}_{1}\right)$. This was followed by application of $100 \% \mathrm{RDF}+$ goat manure as pond silt at 5 $\mathrm{t} / \mathrm{ha}\left(\mathrm{T}_{4}\right)$ and $100 \% \mathrm{RDF}+\mathrm{FYM} 12.5 \mathrm{t} / \mathrm{ha}$ $\left(\mathrm{T}_{13}\right)$. The lower cost of cultivation and net return of $₹ 75740$ and $₹ 60659 /$ ha, respectively were recorded with application of $50 \% \mathrm{RDF}+$ quail manure as pond silt at $5 \mathrm{t} / \mathrm{ha}\left(\mathrm{T}_{11}\right)$.

\section{System equivalent yield}

System equivalent yield of rice-gingelly-maize cropping is influenced by integrated nutrient management (INM) practices (Fig. 1). 
Table.1A Physico - chemical characteristics of the experimental field

\begin{tabular}{|c|c|c|c|c|}
\hline S.No. & Particulars & Values & Methods used & Authors \\
\hline \multicolumn{5}{|c|}{ I. Physical properties } \\
\hline 1. & Clay (\%) & 44.24 & \multirow{5}{*}{$\begin{array}{l}\text { International } \\
\text { pipette method }\end{array}$} & \multirow[t]{5}{*}{ Piper (1966) } \\
\hline 2. & Silt (\%) & 19.3 & & \\
\hline 3. & Coarse sand (\%) & 15.2 & & \\
\hline 4. & Fine sand (\%) & 21.3 & & \\
\hline 5. & Texture & clay loam & & \\
\hline \multicolumn{5}{|c|}{ II. Chemical properties } \\
\hline 1. & $\mathrm{pH}$ & 8.4 & $\begin{array}{l}\text { 1:2 soil: water } \\
\text { suspension }\end{array}$ & Jackson (1973) \\
\hline 2. & $\mathrm{EC}(\mathrm{dS} / \mathrm{m})$ & 0.4 & $\begin{array}{l}\text { Conductometry } \\
\text { (1:2 soil water } \\
\text { suspension) }\end{array}$ & Jackson (1973) \\
\hline 3. & Organic carbon (\%) & 0.5 & $\begin{array}{l}\text { Wet chromic acid } \\
\text { digestion }\end{array}$ & $\begin{array}{l}\text { Walkley and } \\
\text { Black (1934) }\end{array}$ \\
\hline 4. & Available nitrogen $(\mathrm{kg} / \mathrm{ha})$ & 310 & $\begin{array}{l}\text { Alkaline } \\
\text { permanganate }\end{array}$ & $\begin{array}{l}\text { Subbiah and } \\
\text { Asija (1956) }\end{array}$ \\
\hline 5. & $\begin{array}{l}\text { Available phosphorus } \\
\text { (kg/ha) }\end{array}$ & 12.9 & Colorimetry & $\begin{array}{l}\text { Olsen et al., } \\
\text { (1954) }\end{array}$ \\
\hline 6. & $\begin{array}{l}\text { Available potassium } \\
\text { (kg/ha) }\end{array}$ & 482 & $\begin{array}{l}\text { Neutral normal } \\
\text { ammonium acetate }\end{array}$ & $\begin{array}{l}\text { Stanford and } \\
\text { English (1949) }\end{array}$ \\
\hline
\end{tabular}

Table.1B Effect of integrated nutrient management on system yield $(\mathrm{kg} / \mathrm{ha})$ of rice-gingellymaize cropping system (mean of two years)

\begin{tabular}{|c|c|c|c|c|}
\hline Treatment & Rice & REY of Gingelly & REY of Maize & System total \\
\hline$T_{1}-100 \%$ RDF + vermicompost & 6188 & 3359 & 5780 & 15327 \\
\hline$T_{2}-100 \%$ RDF + turkey manure as pond silt & 5525 & 3025 & 5290 & 13840 \\
\hline$T_{3}-100 \%$ RDF + quail manure as pond silt & 5328 & 2919 & 5147 & 13394 \\
\hline$T_{4}-100 \% R D F+$ goat manure as pond silt & 5903 & 3232 & 5532 & 14666 \\
\hline$T_{5}-75 \%$ RDF + vermicompost & 5365 & 2800 & 5432 & 13596 \\
\hline$T_{6}-75 \%$ RDF + turkey manure as pond silt & 4798 & 2475 & 4874 & 12146 \\
\hline$T_{7}-75 \%$ RDF + quail manure as pond silt & 4475 & 2394 & 4549 & 11418 \\
\hline$T_{8}-75 \%$ RDF + goat manure as pond silt & 5115 & 2669 & 5072 & 12856 \\
\hline$T_{9}-50 \%$ RDF + vermicompost & 3980 & 2446 & 4826 & 11252 \\
\hline$T_{10}-50 \%$ RDF + turkey manure as pond silt & 3263 & 2219 & 4165 & 9646 \\
\hline$T_{11}-50 \%$ RDF + quail manure as pond silt & 3100 & 2101 & 3892 & 9093 \\
\hline$T_{12}-50 \%$ RDF + goat manure as pond silt & 3535 & 2321 & 4564 & 10420 \\
\hline $\mathrm{T}_{13}-100 \% \mathrm{RDF}+\mathrm{FYM}$ at $12.5 \mathrm{t} / \mathrm{ha}$ & 5685 & 2981 & 5211 & 13877 \\
\hline
\end{tabular}

Data not statistically analysed 
Table.2 Effect of integrated nutrient management on system economics of rice-gingelly-maize cropping system (mean of two years)

\begin{tabular}{|c|c|c|c|c|c|c|c|c|}
\hline \multirow[t]{2}{*}{ Treatment } & \multicolumn{4}{|c|}{ Cost of cultivation ( $(\bar{h} / \mathrm{ha})$} & \multicolumn{4}{|c|}{ Net return $(₹ / h a)$} \\
\hline & Rice & Gingelly & Maize & Total & Rice & Gingelly & Maize & Total \\
\hline $\mathrm{T}_{1}-100 \% \mathrm{RDF}+$ vermicompost & 29840 & 22930 & 30840 & 83610 & 62973 & 27450 & 55864 & 146287 \\
\hline $\mathrm{T}_{2}-100 \% \mathrm{RDF}+$ turkey manure as pond silt & 29840 & 22930 & 30840 & 83610 & 53035 & 22445 & 48504 & 123984 \\
\hline$T_{3}-100 \%$ RDF + quail manure as pond silt & 29840 & 22930 & 30840 & 83610 & 50073 & 20850 & 46360 & 117283 \\
\hline$T_{4}-100 \%$ RDF + goat manure as pond silt & 29840 & 22930 & 30840 & 83610 & 58698 & 25553 & 52136 & 136387 \\
\hline $\mathrm{T}_{5}-75 \% \mathrm{RDF}+$ vermicompost & 28760 & 21880 & 29790 & 80430 & 51715 & 20113 & 51682 & 123510 \\
\hline$T_{6}-75 \%$ RDF + turkey manure as pond silt & 28760 & 21880 & 29790 & 80430 & 43203 & 15245 & 43314 & 101762 \\
\hline$T_{7}-75 \%$ RDF + quail manure as pond silt & 28760 & 21880 & 29790 & 80430 & 38365 & 14035 & 38450 & 90850 \\
\hline $\mathrm{T}_{8}-\mathbf{7 5 \%} \mathrm{RDF}+$ goat manure as pond silt & 28760 & 21880 & 29790 & 80430 & 47965 & 18160 & 46290 & 112415 \\
\hline $\mathrm{T}_{9}-\mathbf{5 0} \% \mathrm{RDF}+$ vermicompost & 26590 & 21440 & 27710 & 75740 & 33110 & 15245 & 44674 & 93029 \\
\hline$T_{10}-50 \%$ RDF + turkey manure as pond silt & 26590 & 21440 & 27710 & 75740 & 22348 & 11835 & 34754 & 68937 \\
\hline $\mathrm{T}_{11}-\mathbf{5 0 \%} \mathrm{RDF}+$ quail manure as pond silt & 26590 & 21440 & 27710 & 75740 & 19910 & 10075 & 30674 & 60659 \\
\hline $\mathrm{T}_{12}-\mathbf{5 0 \%} \mathrm{RDF}+$ goat manure as pond silt & 26590 & 21440 & 27710 & 75740 & 26435 & 13375 & 40754 & 80564 \\
\hline $\mathrm{T}_{13}-100 \% \mathrm{RDF}+\mathrm{FYM}$ at $12.5 \mathrm{t} / \mathrm{ha}$ & 29840 & 21440 & 30840 & 82120 & 55435 & 23275 & 47320 & 126030 \\
\hline
\end{tabular}

Data not statistically analysed

Table.3 Nutrient analysis of the different manure components

\begin{tabular}{|c|l|c|c|c|}
\hline S.No. & \multicolumn{1}{|c|}{ Manures } & $\begin{array}{c}\text { Nitrogen } \\
\text { (kg/ha) }\end{array}$ & $\begin{array}{c}\text { Phosphorus } \\
\text { (kg/ha) }\end{array}$ & $\begin{array}{c}\text { Potash } \\
\text { (kg/ha) }\end{array}$ \\
\hline 1. & Vermicompost (5t) & 60 & 30 & 40 \\
\hline 2. & Turkey pond silt (5t) & 30 & 15 & 20 \\
\hline 3. & Quail pond silt (5t) & 30 & 10 & 15 \\
\hline 4. & Goat pond silt (5t) & 40 & 20 & 25 \\
\hline 5. & Farm Yard Manure (12 t) & 35 & 15 & 20 \\
\hline
\end{tabular}




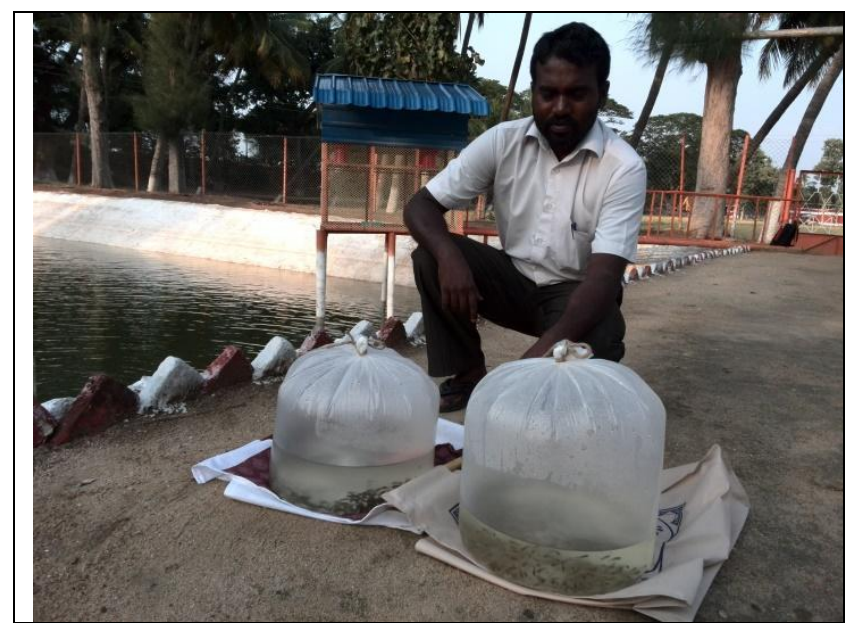

Fingerlings for Integrated Farming System

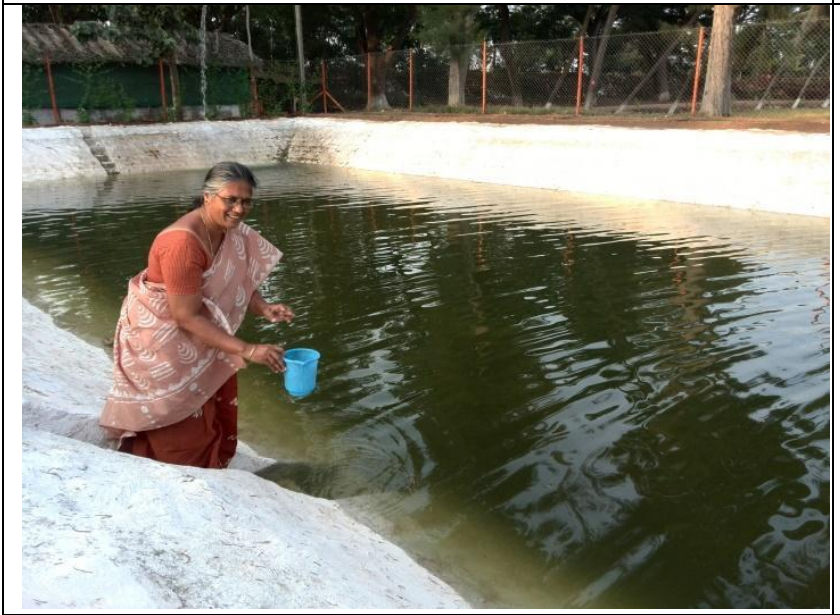

Fingerlings releasing by chairperson

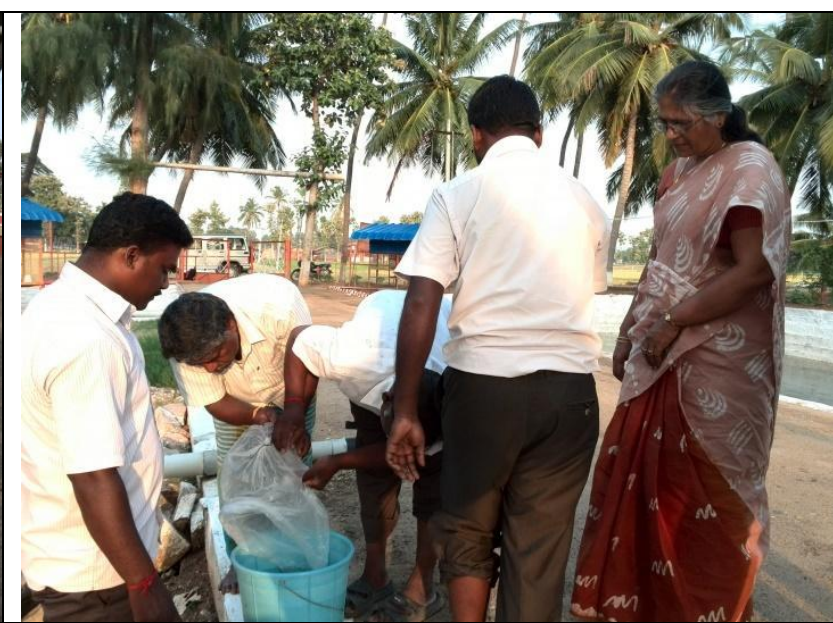

Fingerlings ready for Integrated Farming System

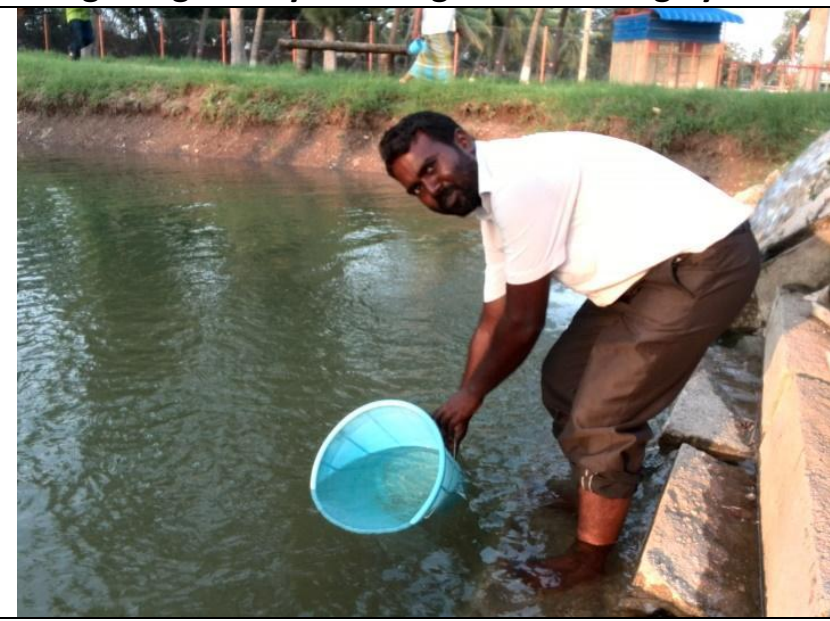

Fingerlings releasing by research scholar

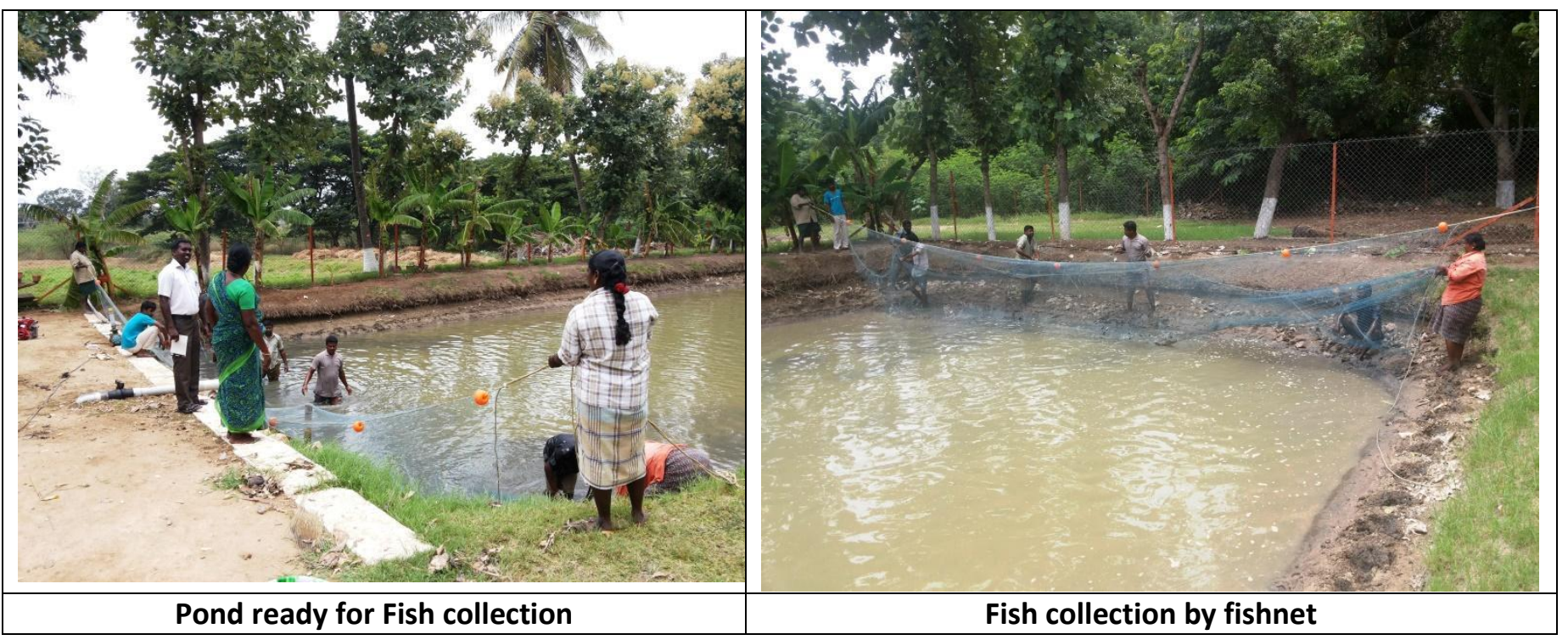



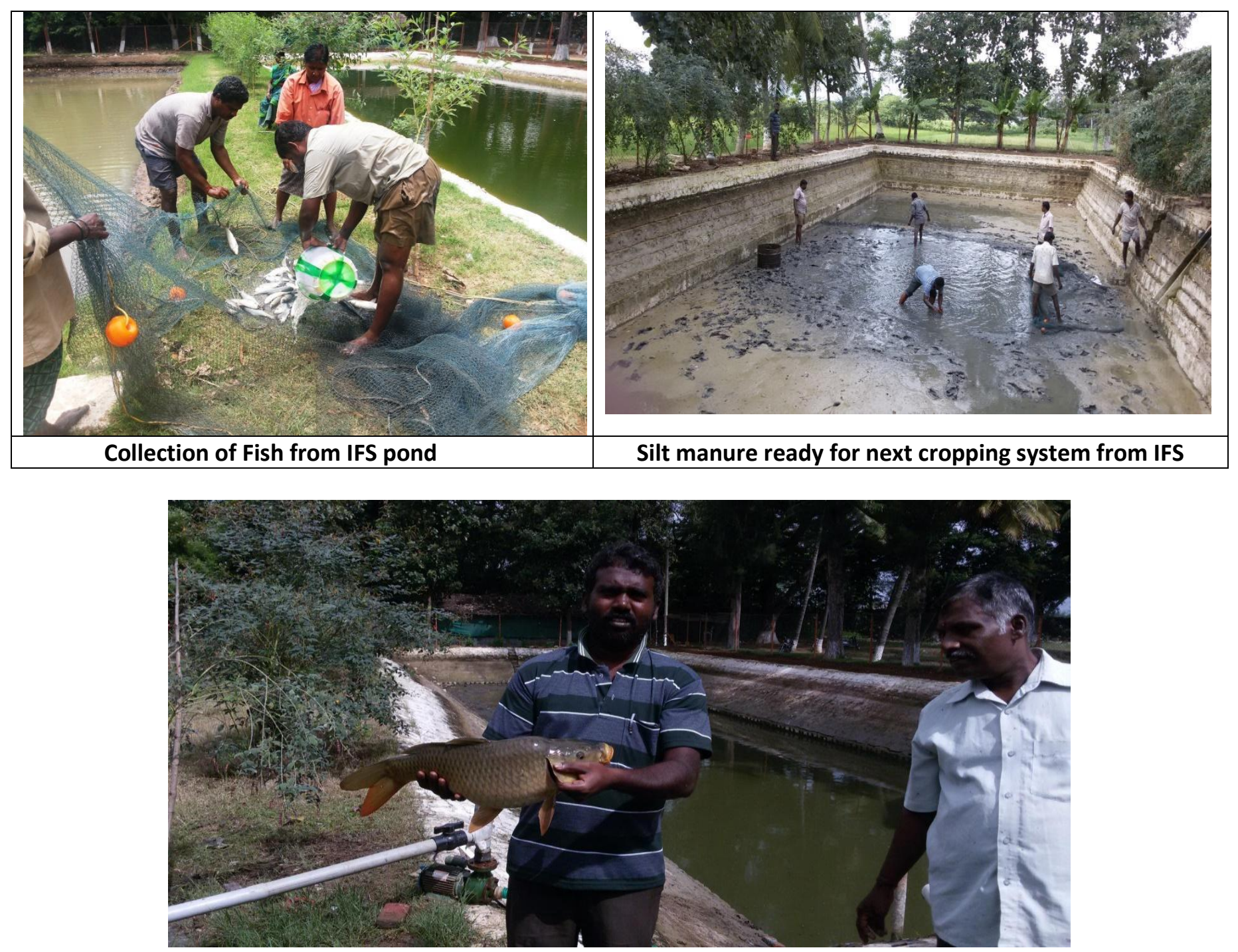

Fig.1 Integrated farming system via a fish weight $3.5 \mathrm{~kg} / 9$ months

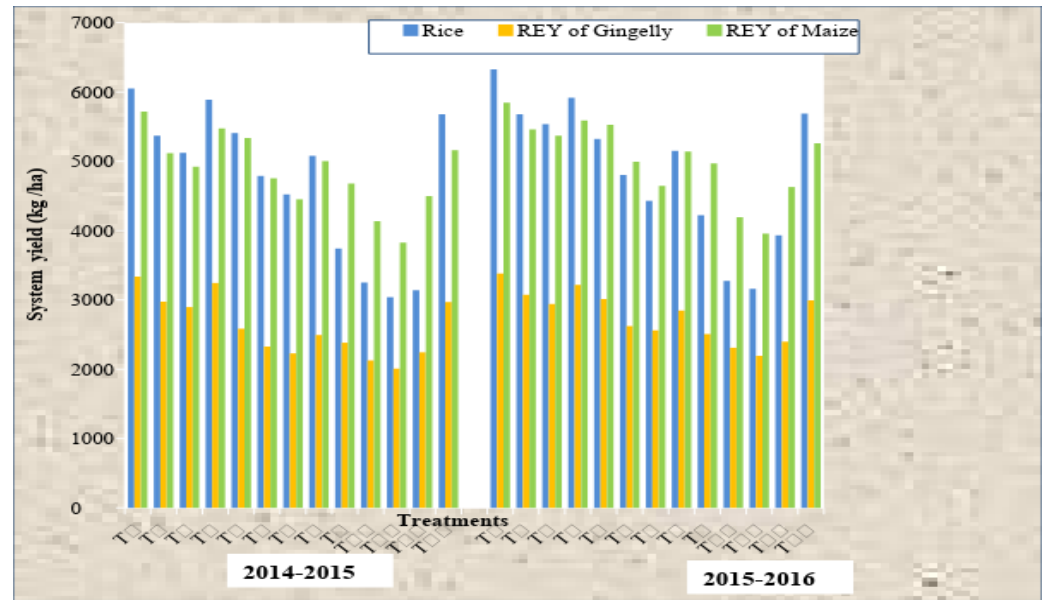


Fig.2 Influence of integrated nutrient management on system yield of rice-gingelly-maize cropping system

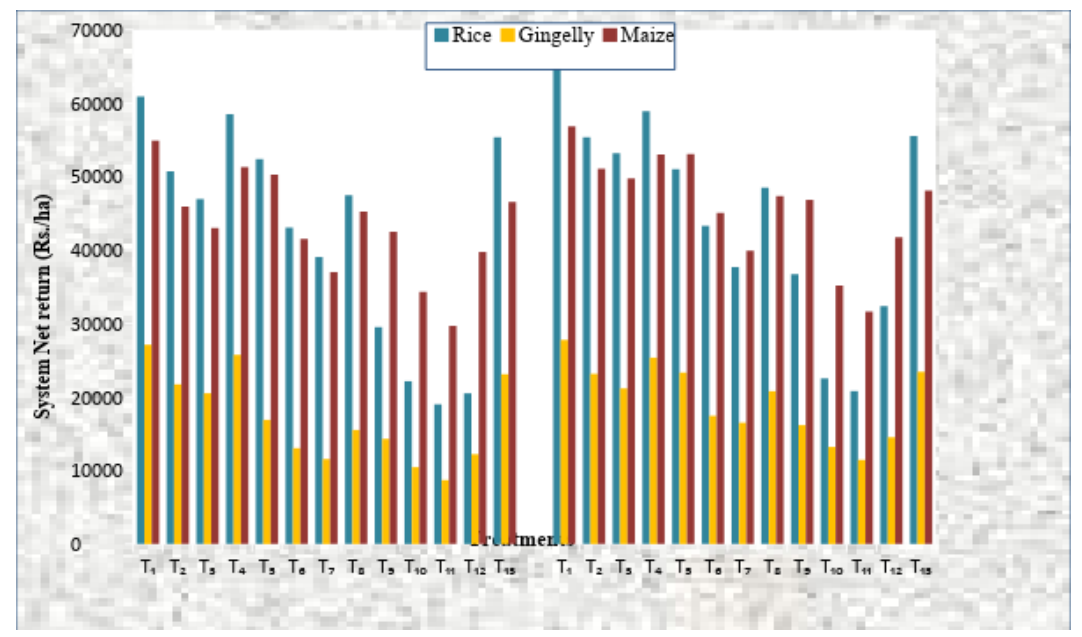

In both the years, mean system equivalent yield of two years revealed that, the application of $100 \% \mathrm{RDF}+$ vermicompost recorded higher system equivalent yield $(15,327 \mathrm{~kg} / \mathrm{ha} /$ year $)$ and it was followed by $100 \% \mathrm{RDF}+5 \mathrm{t} / \mathrm{ha}$ of goat manure $(14,666$ $\mathrm{kg} / \mathrm{ha} /$ year). The higher system equivalent yield with these treatments might be due to integration of organic sources and inorganic fertilizers which enhanced the availability of nutrients for a shorter period as mineralization of nitrogen is more rapid and in turn the losses of inorganic nitrogen due to volatilization, denitrification and leaching etc., would be more. Sarwar et al., (2008) and Ali et al., (2012) also claimed increased system yields of rice with the use of organic manures alone or in combination with chemical fertilizers.

\section{System economics}

System economics of rice-gingelly-maize cropping system was influenced by integrated nutrient management (INM) practices during both the years of study (Fig. 2). Higher system cost of cultivation ( ₹ 83610/ha/year) and net returns ( ₹ 146287 ha/year)) were observed with application of $100 \%$ RDF + vermicompost at $5 \mathrm{t} / \mathrm{ha}$ and it was followed by application of $100 \% \mathrm{RDF}+$ goat manure as pond silt at $5 \mathrm{t} / \mathrm{ha}$ with the cost of cultivation of ₹ 83610/ha/year and net return of ₹ $136387 /$ ha/year of rice- gingelly- maize cropping system. This might be due to the crops low variable cost, higher growth and yield to more gross return was obtained from above treatment and many research work related to the integrated use of fertilizer have found high return to profitable. The similar findings reported by Haque et al., (2001).

Lower cost of cultivation ( ₹ 75740) and net return ( ₹ 60659) were registered with application of $50 \% \mathrm{RDF}+$ quail manure as pond silt at $5 \mathrm{t} / \mathrm{ha}$. The lower system economics was recorded due to imbalanced application of nutrients gave lesser yield thus recording lower economics of the ricegingelly-maize cropping system in both the years. The similar findings are confirmed by Islam et al., (2013).

In conclusion, the mean data two years revealed that higher rice grain equivalent yield $15327 \mathrm{~kg} / \mathrm{ha} /$ year in rice-gingelly-maize as was registered with application of $100 \%$ $\mathrm{RDF}+$ vermicompost at $5 \mathrm{t} / \mathrm{ha}$. This was 
followed by $100 \% \mathrm{RDF}+$ goat manure as pond silt at $5 \mathrm{t} / \mathrm{ha}, 100 \% \mathrm{RDF}+\mathrm{FYM}$ at $12.5 \mathrm{t} / \mathrm{ha}$ and $100 \% \mathrm{RDF}+$ turkey manure as pond silt at $5 \mathrm{t} / \mathrm{ha}$. Mean data over two years stated that the highest cost of cultivation (83610/ha/year) and net returns of 146287/ha/year was recorded with application of $100 \% \mathrm{RDF}+$ vermicompost at $5 \mathrm{t} / \mathrm{ha}$ in rice-gingelly-maize cropping system. This was followed with application of $100 \%$ RDF + goat manure as pond silt at $5 \mathrm{t} / \mathrm{ha}$ and $100 \%$ $\mathrm{RDF}+\mathrm{FYM}$ at $12.5 \mathrm{t} / \mathrm{ha}$.

\section{Recommendations}

In rice-gingelly-maize cropping system for rice and gingelly crops application of $100 \%$ recommended dose of fertilizer along with either 5 t/ha vermicompost (or) 5 t/ha of goat manure as pond silt and for maize crop $75 \%$ recommended dose of fertilizer along with 5 t/ha vermicompost can be recommended for better yield and economics.

\section{References}

Ali, R.I., T.H. Awan, M. Ahmad, M.U. Saleem and M. Akhtar. 2012. Diversification of rice- based cropping systems to improve soil fertility, sustainable productivity and economics. J. Anim. Plant Sci., 22(1): 108-112.

Carter, M.R. 2002. Soil quality for sustainable land management: Organic matter and 14. aggregation interactions that maintain soil functions. Agron. J., 94: 38-47.

Cassman, K.G. 1999. Ecological intensification of cereal production systems: Yield potential, soil quality, and precision agriculture. Proc. Natl. Acad. Sci. USA, 96: 5952-5959.

Erenstein, O. and V. Laxmi. 2008. Zero tillage impacts in India's rice-wheat systems:
A review. Soil and Tillage Res., 100(1-2): 1-14.

FAO. 2001. Report of the $2^{\text {nd }}$ Research coordination meeting of the FAO/IAEA coordinated research project on the use of nuclear techniques for developing integrated nutrient and water management practices for Agro forestry systems. 7-11 May, Kuala Lumpur. IAEA 311-D1-RC-735.2.

Haque, M.Q., M.H. Rahman, I. Fokrul, Jan, Rijmpa, and M.M. Kadir. 2001. Integrated nutrient management in relation of soil fertility and yield sustainability under wheat- mung-T. aman cropping pattern. J. Biol. Sci., 1(8): 731-734.

Hobbs, P.R., K. Sayre and R. Gupta. 2008. The role of conservation agriculture in sustainable agriculture. Phil. Trans. R. Soc. Biol. Sci., 363: 543-555.

Islam, M., S. Akhter, M. Nik, Majid, J. Ferdous and M.S. Alam. 2013. Integrated nutrient management for potato (Solanum tuberosum) in grey terrace soil. Australian J. Crop Sci., 7(9): 1235-1241.

Jackson, M.L. 1973. Soil Chemistry analysis. Prentice-Hall of India Pvt. Ltd., New Delhi: 1-498. Soil microbial biomass. Crop Res., 8(1): 28-31.

Johnston, A.E., P.R. Poulton and K. Coleman. 2009. Soil organic matter: Its importance in sustainable agriculture and carbondioxide fluxes. Adv Agron, 101: 1-57.

Olsen, R.R., C.L. Cole, F.S. Watnabe and D.A. Dean. 1954. Estimation of available $P$ in soils by extraction with sodium bicarbonate, USDA Circ. Science: 933-940.

Piper, C.S. 1966. Soil and plant analysis. Hans Publishers, Bombay.

Sarwar G., N. Hussain, H. Schmeisky, S. Suhammad, M. Ibrahim and $\mathrm{S}$. 
Ahmad. 2008. Efficiency of various organic residues for enhancing ricewheat production under normal soil conditions. Pak. J. Bot., 40(5): 21072113.

Six, J., C. Feller, K. Denef, S.M. Ogle, J.C.D. Sa and A. Albrecht. 2002. Soil organic matter, biota and aggregation in temperate and tropical soils - Effects of no-tillage. Agronomie, 22(7-8): $755-775$.

Stanford, S. and L. English. 1949. Use of flame photometer in rapid soil tests of K and Ca. Agron. J., 4: 446-447.

Subbiah, B.V. and G.L. Asija. 1956. A rapid procedure for estimation of available nitrogen in the soil. Curr. Sci., 25: 259-260.

Thiyagarajan, T.M., and R. Selvaraju. 2001. Water saving in rice cultivation in India. In: Proceedings of an international workshop on water saving rice production systems. Nanjing University, China. PP.15-45.

Vanden Bygaart, A.J., E.G. Gregorich and D.A. Angers. 2003. Influence of agricultural management on soil organic carbon: A compendium and assessment of Canadian studies. Can. J. Soil Sci., 83: 363-380.

Walkley, A. and C.A. Black. 1934. An examination of Degtjaroff method for determining soil organic matter and proposed modification of the chromic acid titration methods. Soil Sci., 37: 29-34.

West, T.O. and W.M. Post. 2002. Soil organic carbon sequestration rates by tillage and crop rotation: A global data analysis. Soil Sci. Soc. Am. J., 66(6): 1930-1946.

\section{How to cite this article:}

Maruthupandi, K. and Jayanthi, C. 2018. Contingent Crop Planning for Delayed Onset of Monsoon in Scarce Rainfall Zone of Andhra Pradesh. Int.J.Curr.Microbiol.App.Sci. 7(09): 3564-3574. doi: https://doi.org/10.20546/ijcmas.2018.709.442 